\title{
Chytridiomycosis in frogs of Mount Gede Pangrango, Indonesia
}

\author{
M. D. Kusrini ${ }^{1, *}$, L. F. Skerratt ${ }^{2}$, S. Garland ${ }^{3}$, L. Berger ${ }^{2}$, W. Endarwin ${ }^{1}$ \\ ${ }^{1}$ Departemen Konservasi Sumberdaya Hutan dan Ekowisata, Fakultas Kehutanan, Institut Pertanian Bogor, \\ Kampus Darmaga, PO Box 168, Bogor 1600, Indonesia \\ ${ }^{2}$ Amphibian Disease Ecology Group, School of Public Health, Tropical Medicine and Rehabilitation Sciences, \\ James Cook University, Townsville 4811, Australia \\ ${ }^{3}$ Amphibian Disease Ecology Group, School of Veterinary and Biomedical Sciences, James Cook University, \\ Townsville 4811, Australia
}

\begin{abstract}
Batrachochytrium dendrobatidis $(B d)$ is a fungus recognised as one of the causes of global amphibian population declines. To assess its occurrence, we conducted PCR diagnostic assays of 147 swab samples, from 13 species of frogs from Mount Gede Pangrango National Park, Indonesia. Four swab samples, from Rhacophorus javanus, Rana chalconota, Leptobrachium hasseltii and Limnonectes microdiscus, were positive for $B d$ and had low to moderate levels of infection. The sample from $L$. hasseltii was from a tadpole with mouthpart deformities and infection was confirmed by histology and immunohistochemistry. An additional sample from Leptophryne cruentata showed a very low level of infection ( $\leq 1$ zoospore equivalent). This is the first record of $B d$ in Indonesia and in Southeast Asia, dramatically extending the global distribution of $B d$, with important consequences for international amphibian disease control, conservation and trade. Consistent with declines in amphibian populations caused by $B d$ in other parts of the world, evidence exists for the decline and possible extirpation of amphibian populations at high elevations and some decline with recovery of populations at lower elevations on this mountain. Therefore, it is essential to manage $B d$ in Indonesia where it is likely to be threatening amphibian populations. This will require a national strategy to mitigate the spread of $B d$ in Indonesia and neighboring countries as well as the impact of that spread. It is also important to collect information on the extent of the impact of $B d$ on frog populations in Indonesia.
\end{abstract}

KEY WORDS: Batrachochytrium dendrobatidis - Chytridiomycosis - Indonesia - Southeast Asia · Emerging infectious disease

Resale or republication not permitted without written consent of the publisher

\section{INTRODUCTION}

Batrachochytrium dendrobatidis $(B d)$ causes the disease chytridiomycosis, a spreading fungal disease responsible for declines and extinctions of amphibian populations around the world (Berger et al. 1998, 1999, Skerratt et al. 2007). To date, $B d$ has been identified in amphibian populations on all continents where amphibians exist (Berger et al. 1998, Lips 1999, Longcore et al. 1999, Bosch et al. 2001, Muths et al. 2003, Bell et al. 2004, Lips et al. 2004, Weldon et al. 2004), including recent reports from Asia. $B d$ has been detected in captive and wild amphibians in Japan (Une
2007), although wild amphibians in Hong Kong and Thailand currently appear free of $B d$ (Rowley et al. 2007, McLeod et al. 2008).

Western Java has at least 25 native amphibian species, including some that are endangered, near threatened or vulnerable. The climate of the region, particularly at high elevation sites, is suitable for $B d$ and models predicting the global distribution of $B d$ based on environmental variables have predicted that the montane forests of Java and Sumatra are highly favorable for infections (Ron 2005). For instance, the temperature in Mount Gede Pangrango National Park and Mount Halimun Salak in West Java, which is typically 
between 13.5 to $28^{\circ} \mathrm{C}$ diurnally, and the relative humidity of 63 to $100 \%$ (Kusrini et al. 2007a), are suitable for $\mathrm{Bd}$ which grows best at 17 to $23^{\circ} \mathrm{C}$ and requires moist conditions (Piotrowski et al. 2004). The introduction of bullfrogs Rana catesbeiana to Indonesia in 1982 as part of a government program to increase frog leg exports (Susanto 1989) could have been a potential route for introducing $\mathrm{Bd}$ into Indonesia. $R$. catesbeiana is considered a likely carrier of $\mathrm{Bd}$ because populations may have high infection rates and individuals neither show obvious clinical signs nor die from the infection (Daszak et al. 2004, Hanselmann et al. 2004). These factors make Indonesia, and West Java in particular, an important location for the conduct of a systematic survey of $B d$ in the Asian region.

A previous survey for $B d$ in Indonesia used histological analysis to assess samples of toe clips from 3 edible frogs (Fejervarya limnocharis-iskandari complex, F. cancrivora and Limnonectes macrodon) taken mostly from rice fields and adjacent areas in West Java during 2001-2004 (Kusrini 2005). As expected, Bd was not detected in any of these samples considering the climate and management of rice fields and the susceptibility of $B d$ to desiccation. Most rice fields in Indonesia occur in warm lowland areas and experience periodic dry conditions that can last for more than a month, potentially eliminating $B d$ from the environment. It is likely that species at higher elevations in association with more permanent water may be at greater risk (Speare et al. 2005, Skerratt et al. 2008). One such species is the bleeding toad Leptophryne cruentata (Kusrini et al. 2005, IUCN 2008), an endemic frog from West Java that appears to have undergone an unexplained dramatic population decline. As $B d$ is known to be responsible for similar enigmatic declines in other parts of the world, efforts should be made to determine if $B d$ is present in L. cruentata and other sympatric species in the area. The objective of our research was to assess the occurrence of $B d$ in the frogs of Gede Pangrango National Park.

\section{MATERIALS AND METHODS}

A survey was conducted from December 2006 to March 2007, along the Cibodas Trail of Mount Gede Pangrango National Park and at an additional site at Bodogol. The survey was conducted in conjunction with amphibian monitoring at the National Park. At each location, we surveyed a $400 \mathrm{~m}$ transect of stream and also conducted a 3 to $4 \mathrm{~h}$ search of terrestrial habitats on 4 consecutive nights.

The Cibodas Trail is the main route to the summit of Mount Gede Pangrango and is popular with hikers. The survey on the Cibodas Trail was conducted mainly in locations previously surveyed either by Liem (1971), during his survey for amphibians in 1961-1964 or by Kusrini et al. (2005) in 2003-2004. The selection of study area was based on several criteria: accessibility, a representative range of elevations, and suitable amphibian habitat such as the availability of water bodies. Samples were collected at the following locations on the Cibodas Trail: (1) Ciwalen (1361-1420 m asl); (2) Telaga Biru (1571 m asl); (3) Curug Cibeureum (1685 m asl); (4) Rawa Denok (1699-1795 m asl); (5) Lebak Saat (2250-2500 m asl); and (6) Alun-alun Surya Kencana (2748 m asl). Bodogol (703-814 m asl) is located outside the Cibodas Trail and was previously managed by Perum Perhutani (Plantation Estates) before inclusion in the Mount Gede Pangrango National Park (Fig. 1). The collection sites include submontane to montane forests with fast-flowing rocky streams, subalpine forests and a subalpine grasslandedelweiss meadow with an ephemeral creek.

Each frog was captured by hand using new disposable plastic bags to cover the hands in order to avoid transmitting $B d$ between individuals. We followed the hygiene protocol described by Speare et al. (2004). Information on locality, weather, time, elevation, habitat type and sex of the collected samples were recorded. We swabbed the posterior ventral surfaces of the lower abdomen, thighs, and all hands and feet of individual frogs twice. We sampled $\sim 10$ ind. of each species, but sampled $75 \%$ of individuals of Leptophryne cruentata because of its recent decline. A total of 147 swabs were collected from 13 species of frogs. The number of frogs swabbed is only a small fraction of the total number of frogs encountered during the survey (Table 1). In addition, we examined 5 tadpoles from each of 9 species encountered at each survey site with a hand lens to detect mouthpart abnormalities according to methods in Obendorf (2005). Tadpoles from 4 of the 13 species encountered (Table 1), namely Microhyla achatina, M. palmipes, Megophrys montana and Philautus aurifasciatus, were not examined because of the natural absence of an oral disk in the first 3 species and the absence of a tadpole stage in the last species. Examination of tadpole mouthparts has been used to indicate the likelihood of chytridiomycosis in several species (Knapp \& Morgan 2006, Retallick et al. 2006). Only one tadpole that showed abnormalities in its mouthparts was swabbed for PCR testing. Swabs were taken only for individuals captured on the first day of sampling, except for L. cruentata, to avoid repeatedly sampling the same individual. Captured individuals of L. cruentata were swabbed and then housed temporarily before being released at the end of the survey.

All frogs sampled were released at their location of capture, except for a tadpole of Leptobrachium hasseltii 


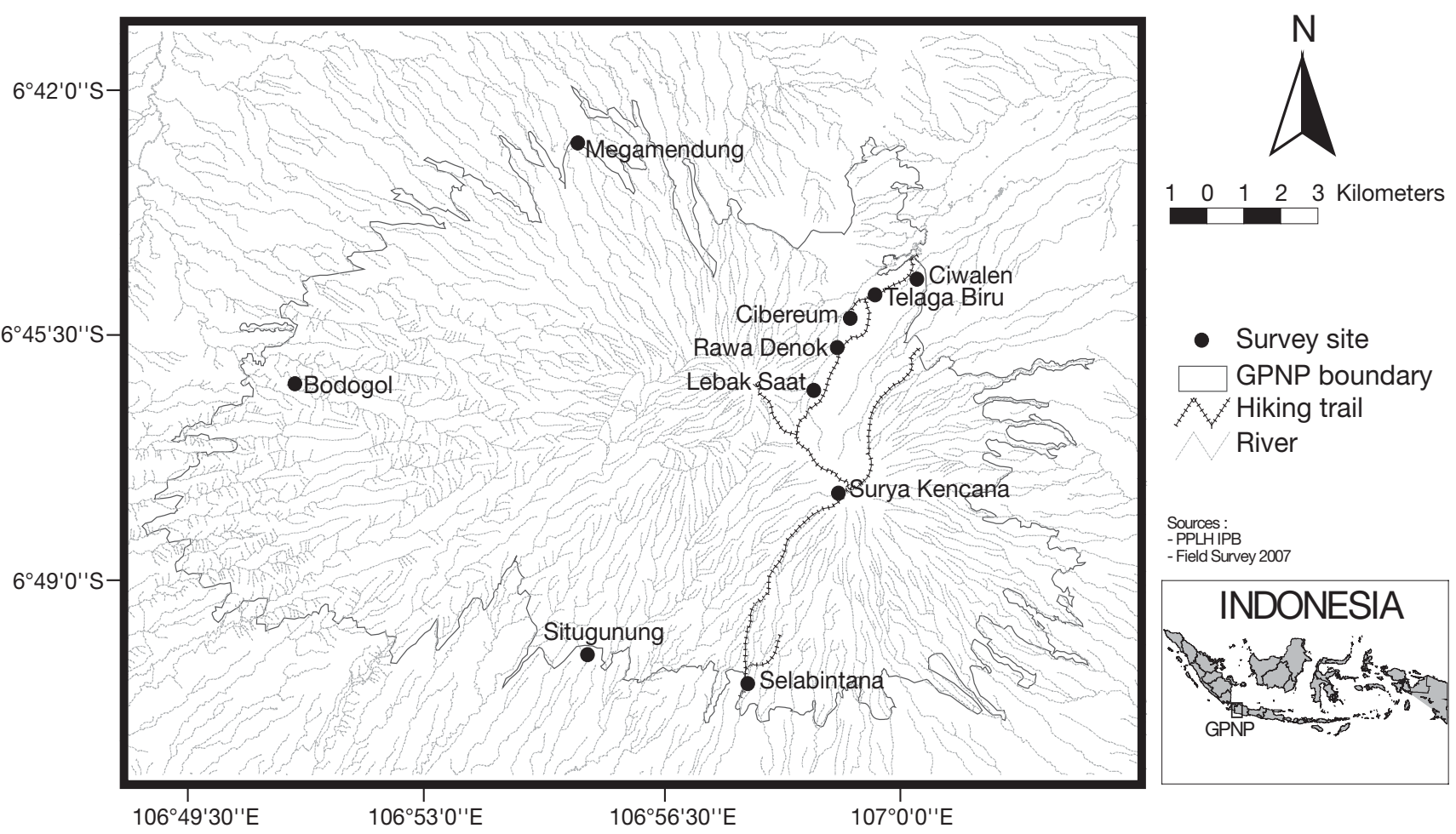

Fig. 1. Mount Gede Pangrango National Park (GPNP), showing location of infection at Cibodas Trail. Ciwalen (1361-1420 m asl): $06^{\circ} 44.677^{\prime} \mathrm{S}, 107^{\circ} 0.267^{\prime} \mathrm{E}_{\text {; }}$ Telaga Biru (1571 m asl): 06 $44.909^{\prime} \mathrm{S}, 1^{\circ} 106^{\circ} 59.644^{\prime} \mathrm{E}_{\text {; }}$ Cibeureum (1685 m asl): $06^{\circ} 45.232^{\prime} \mathrm{S}$, $106^{\circ} 59.177^{\prime} \mathrm{E}$

which showed severe mouthpart loss and was euthanized by fixing in $70 \%$ ethanol. Swab samples and the tadpole were transported to Australia under a permit issued by the Australian Quarantine and Inspection Service to the James Cook University Amphibian Disease Ecology Group (Permit No. 200520790). Samples from the same species and location were pooled into 71

Table 1. Number of frogs swabbed per species in Mount Gede Pangrango National Park

\begin{tabular}{|lcccccc|}
\hline \multirow{2}{*}{ Species } & \multirow{2}{*}{$\begin{array}{c}\text { Total } \\
\text { field }\end{array}$} & Female & Male & Juvenile & Tadpole \\
\cline { 6 - 7 } & 144 & 3 & 7 & & 0 \\
Huia masonii & 51 & & 4 & & 1 \\
Leptobrachium hasseltii & 35 & & 10 & & 0 \\
Leptophryne borbonica & 53 & 30 & 8 & 3 & 0 \\
Leptophryne cruentata & 173 & 2 & 6 & 2 & 0 \\
Limnonectes kuhlii & 34 & 5 & 2 & 3 & 0 \\
Limnonectes microdiscus & 16 & 1 & 5 & 4 & 0 \\
Megophrys montana & 7 & & & 1 & 0 \\
Microhyla achatina & 16 & 1 & 9 & & 0 \\
Microhyla palmipes & 52 & 1 & 10 & 1 & 0 \\
Philautus aurifasciatus & 69 & 3 & 2 & 3 & 0 \\
Rana chalconota & 160 & 1 & 8 & 1 & 0 \\
Rana hosii & 85 & 1 & 9 & & 0 \\
Rhacophorus javanus & & & & & \\
\hline
\end{tabular}

batches containing up to 3 samples each. Diagnostic PCR tests for $B d$ infection were performed for each batch using the Taqman RT-PCR primers and probe described by Boyle et al. (2004). The sensitivity of this test on individual samples of wild rainforest stream frogs from Queensland is $\sim 75 \%$ (L. F. Skerratt et al. unpubl. obs.). Specificity was estimated to be $\sim 100 \%$ for the procedure used to test these samples (S. Garland et al. unpubl. obs.). Individual samples from batches that tested positive were re-tested. Each PCR test was run in triplicate, with the concentration of $B d$ DNA in zoospore equivalents calculated using the Corbett RotorGene software. The result was considered indeterminate when only 1 or 2 wells were positive and the amount of DNA detected was low. Histological and immunohistochemical analyses were conducted on the tadpole of $L$. hasseltii following the methods of Berger et al. (2000) and Hyatt et al. (2007), respectively. The immunoperoxidase stain employed rabbit 667 anti- $B d$ polyclonal antibody (Berger et al. 2002). 


\section{RESULTS}

Samples from 4 species (Rhacophorus javanus, Rana chalconota, Leptobrachium hasseltii and Limnonectes microdiscus) tested positive for $B d$ (Table 2). All of the positive samples, except for the one from L. microdiscus, were taken from aquatic habitats (streams and swamps) within the Cibodas Trail. Although taken from a terrestrial habitat, samples of $L$. microdiscus were collected near streams. Samples of $R$. javanus, $R$. chalconota, L. hasseltii and L. microdiscus were clearly positive and indicated that the level of infection was likely low to moderate. In addition, a sample from Leptophryne cruentata resulted in only 1 positive PCR reaction from 3 replicates and very low levels of $B d$ DNA, which is considered indeterminate due to the increased likelihood of DNA contamination.

The tadpole of Leptobrachium hasseltii with abnormal mouthparts had a grossly sparse presence of labial teeth and loss of the dark colour from most of the jaw sheath, except medially (Fig. 2). The tadpole was at Gosner stage 25 with body and tail length of 10 and $9 \mathrm{~mm}$, respectively. Histology of the mouthparts revealed moderate infection with mixed stages of $B d$ along the surface of the posterior jaw sheath, including mature sporangia with zoospores and discharge tubes. Clusters of mainly empty stages of $B d$ were seen on the tips of tooth ridges (Fig. 3a). Labial teeth were often missing from the rounded tooth ridges. Sporangia were strongly stained with the immunoperoxidase stain (Fig. 3b).

\section{DISCUSSION}

Results confirm the presence of Batrachochytrium dendrobatidis in Indonesian wild frogs, which is the first report for Southeast Asia. This is the second report on the presence of $B d$ in wild frogs of Asia, a continent
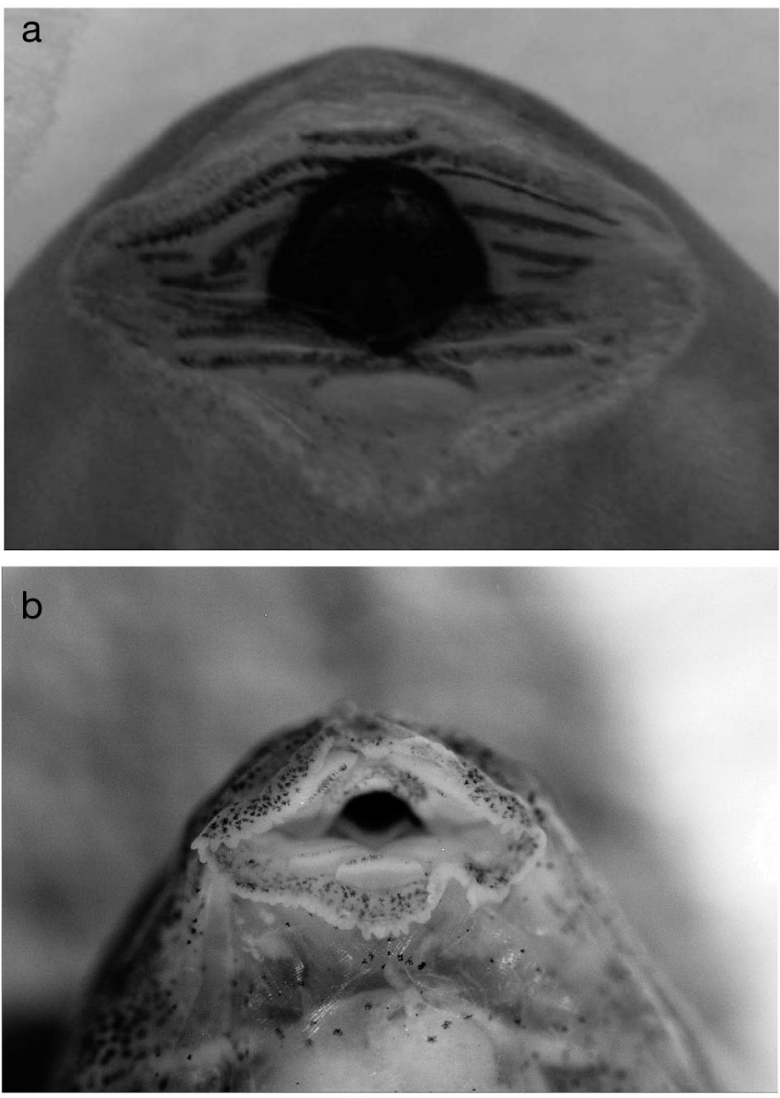

Fig. 2. Leptobrachium hasseltii. (a) Mouthparts from a normal tadpole with a dark central jaw sheath surrounded by rows of teeth. (b) Mouthparts from infected tadpole collected from Ciwalen (Mount Gede Pangrango National Park) showing loss of dark colour from the jaw sheath and loss of labial teeth resulting in pale tooth rows

where data on the distribution of $B d$ is lacking (Olson \& Ronnenberg 2008). We did not conduct probability analyses of the likelihood that $B d$ is present in Indonesia given the high specificity of our PCR test and the visual confirmation of infection by histology and

Table 2. Species infected with Batrachochytrium dendrobatidis. SVL: snout-vent length

\begin{tabular}{|c|c|c|c|c|c|c|}
\hline Species & Sex/Stage & SVL (mm) & Mass $(g)$ & $\begin{array}{c}\text { Zoospore } \\
\text { equivalents } \\
\text { sample }^{-1}\end{array}$ & $\begin{array}{c}\text { No. } \\
\text { of wells }\end{array}$ & Date collected \\
\hline \multicolumn{7}{|l|}{ Telaga Biru } \\
\hline Rhacophorus javanus & Male & 41.66 & 7.15 & 385 & 3 & 1 Jan 2007 \\
\hline Rana chalconota & Juvenile & 42.60 & 2.50 & 72 & 3 & 1 Jan 2007 \\
\hline \multicolumn{7}{|l|}{ Ciwalen } \\
\hline Leptobrachium hasseltii & Tadpole & - & - & 22 & 3 & 17 Jan 2007 \\
\hline Limnonectes microdiscus & Juvenile & 19.62 & 0.75 & 3 & 3 & 17 Jan 2007 \\
\hline \multicolumn{7}{|l|}{ Cibeureum } \\
\hline Leptophryne cruentata & Juvenile & 23.72 & 1.30 & $\leq 1$ & 1 & 31 Dec 2006 \\
\hline
\end{tabular}



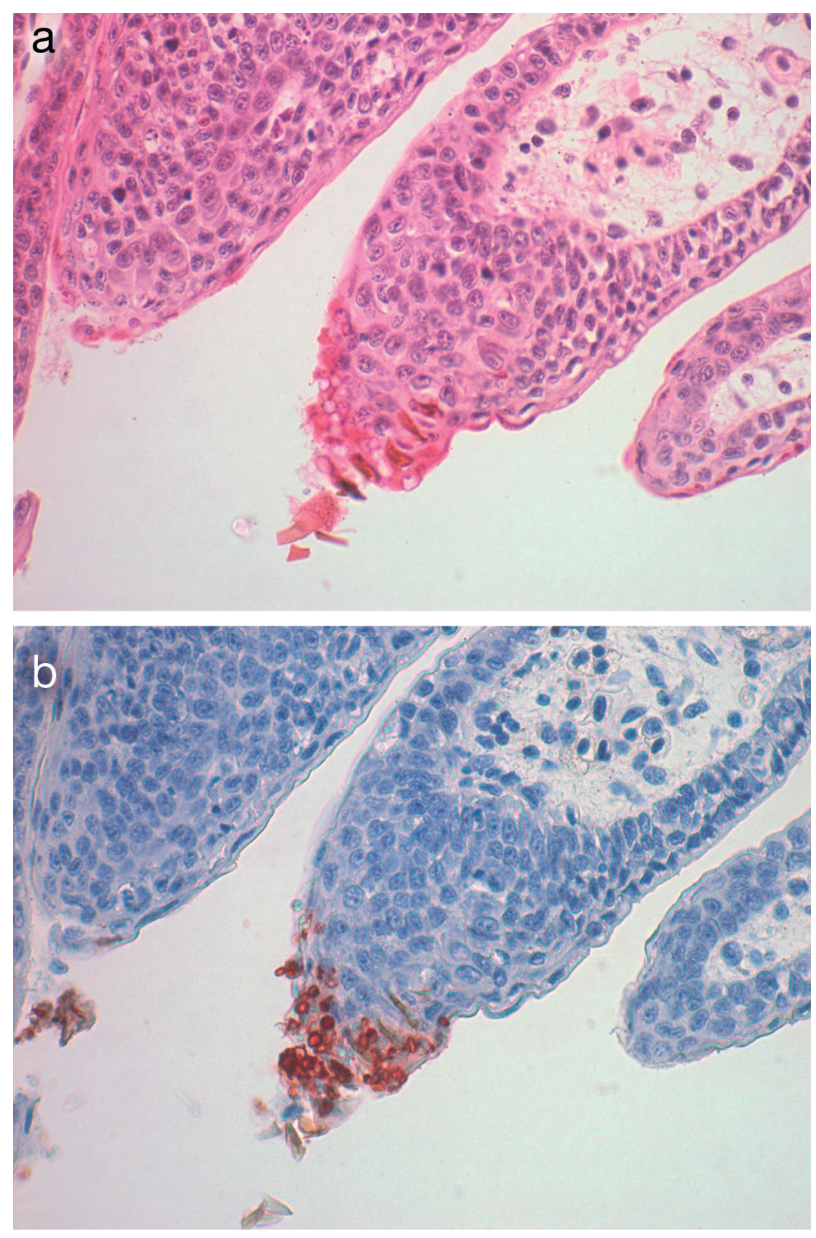

Fig. 3. Leptobrachium hasseltii. (a) Histological section of tadpole mouthparts with a cluster of Batrachochytrium dendrobatidis sporangia on the edge of a tooth ridge (haematoxylin and eosin stain). (b) Same section as in (a) but with sporangia clearly stained brick red by immuno-peroxidase

immunohistochemistry. We are unable to report the prevalence of $B d$ infection in Mount Gede Pangrango amphibian populations because of our limited survey. The detection of $B d$ in our survey is consistent with Ron's model (2005) on the potential distribution of $B d$, and indicates that $B d$ may exist in other mountainous areas of West Java, such as in Mount Halimun Salak, as well as in other parts of Indonesia.

The test result for Leptophryne cruentata is at the limit of detection of $B d$ DNA. The possibility of this result being due to DNA contamination during sample collection, pre-sampling contact with an infected frog or during the PCR test rather than direct infection, is very low. Nevertheless, we have regarded the result as indeterminate because we wish to be certain before declaring a species as infected.

Three of the frog species infected with $B d$ (Rana chalconota, Leptobrachium hasseltii and Limnonectes microdiscus) are widely distributed in Indonesia. Rhacophorus javanus is endemic to Java while Leptophryne cruentata is endemic to West Java. There are no reports of decline of these species, except for $L$. cruentata (Iskandar 1998, Kusrini et al. 2005) which is listed by the IUCN as critically endangered. During the 1960s, L. cruentata was found in abundance at most elevations in Cibodas Trail and was the second most abundant frog encountered after $R$. chalconota (Liem 1971). The decline appeared to have occurred throughout its distribution in the Park prior to the 1990s as Iskandar (1998) mentioned that L. cruentata was absent from Cibeureum and Kusrini et al. (2005) reported only 4 ind. during a survey in 2004-2005. However in 2007, 53 ind. of L. cruentata were found (Kusrini et al. 2007b). As the monitoring in 2004-2005 and 2007 was conducted by the same team using standardized methodology, search effort between the survey periods was consistent (Kusrini et al. 2007b). Normal fluctuations in amphibian populations (Marsh 2001, Pechmann et al. 1991, Pechmann \& Wilbur 1994) necessitate data collection over numerous years to detect abnormal population declines. Due to the lack of long-term monitoring programs for any species in Mount Gede Pangrango National Park, we are uncertain whether the low number of L. cruentata during 2004-2005 and their absence reported by Iskandar (1998) reflect an abnormal decline of the species throughout its distribution in the Park, or if the decline is related to the introduction of $B d$ into the Park.

At the highest elevations within the Park, however, declines are more obviously abnormal. The highest elevation in Mount Gede Pangrango that currently harbours frog populations is Rawa Denok (1699$1795 \mathrm{~m}$ asl). Liem's (1971) survey found the highest elevation harbouring frog populations to be at Lebak Saat (2250-2500 m asl) which only harboured Leptophryne cruentata; however, recent attempts to find frogs in Lebak Saat were unsuccessful (Kusrini et al. 2005, 2007b). Records at the Museum Zoologicum Bogoriense (MZB) showed that during Liem's survey in 1964, a third of the archived specimens of $L$. cruentata consisted of specimens from Lebak Saat. There are no archived specimens from Lebak Saat after 1964 or any report on the occurrence of $L$. cruentata from Lebak Saat, although specimens from Cibeureum were deposited in the 1970s and 1990s. It is possible that $L$. cruentata has been extirpated from its upper distribution. However, because there were no systematic surveys between 1964 and 2004, we are uncertain of the timing of the decline and possible extirpation. Elsewhere in the world, amphibian population declines at high elevations associated with cooler temperatures, have been caused by $B d$ (Skerratt et al. 2007). The role of climate change in amphibian extinctions due to $B d$ is 
uncertain but if it has a role, it is likely to be of low relative importance compared with the spread of this pathogen (Skerratt et al. 2007, Laurance 2008, Lips et al. 2008). This does not preclude the potential for severe climate change to directly impact amphibian populations or for it to alter disease dynamics where $B d$ is endemic or change the favourable geographic range of $B d$. Therefore, future work should prioritize assessment of $B d$ prevalence from archived specimens from MZB to determine if the disappearance of $L$. cruentata from high elevations and its concurrent decline in other areas of the Park are connected with the introduction of this fungus. Management of $B d$ should also be prioritized as it is likely to be a threat to the conservation of $L$. cruentata whose limited distribution makes its conservation a high concern.

During the survey, frogs with clinical signs of chytridiomycosis such as abnormal posture or behavior (Berger et al. 1999) were not found. Rana chalconota, Limnonectes microdiscus and Rhacophorus javanus were often found sitting unprotected during the day and Leptophryne cruentata were sometimes found sitting on rocks within the spray zone of waterfalls during the day (M. D. Kusrini pers. obs.). R. javanus, the endemic Javanese tree frog, was usually found 1 to $2 \mathrm{~m}$ above the ground, often near the stream, sitting and calling in leaves and branches at night. Although not a true tree frog, $R$. chalconota is usually found sitting in branches or leaves near water, during night or day. It is known that $B d$ is killed when exposed to temperatures $>30^{\circ} \mathrm{C}$ (Longcore et al. 1999) and elevated temperatures can cure frogs from infection (Woodhams et al. 2003, Berger et al. 2004, Retallick \& Miera 2007). Although there are no published data on the behavior of the infected species in this study, anecdotal observations suggest that normal behavior of $R$. chalconota, $L$. miscrodiscus and $R$. javanus might help prevent lethal infections from $B d$ by occupying microclimates unfavourable to $B d$. However, we suggest that further research should be carried out to determine the impact of $B d$ on these species, especially on L. cruentata, for the reasons stated above.

Only one tadpole examined (Leptobrachium hasseltii) showed distinct gross abnormalities of the mouthparts (Fig. 2). The mature frog of L. hasseltii is terrestrial and is usually found in abundance in leaf litter. The tadpoles are quite large (snout-vent length up to $73 \mathrm{~mm}$ ) suggesting the tadpole stage to be of long duration (Iskandar 1998). It is believed that $B d$ mainly kills post metamorphic stages of frogs (Berger et al. 1998, 1999) and larvae can act as reservoir hosts (Daszak et al. 1999, 2003). Since mature L. hasseltii rarely venture to water except during breeding periods, it is possible that the tadpole stages are more susceptible to $B d$ infection.
The streams of the Cibodas trail in Mount Gede Pangrango are connected. The main stream flows from the top of the mountain and branches into Cibeureum, Telaga Biru and Ciwalen, which may explain the occurrence of $B d$ in all 3 locations. Since the mountain itself is a protected habitat, conservation efforts should involve long-term monitoring studies of amphibians in this area, determining the cause of any amphibian declines and managing threats to amphibian conservation.

There is concern of $B d$ spreading through the international amphibian trade (Daszak et al. 2006, Fisher \& Garner 2007). The report of Une (2007) has clearly shown $B d$ infected species imported to Japan for the pet trade. At least 4 exotic frog species are found in Indonesia: Rana catesbeiana was introduced for captive breeding (Susanto 1989), Xenopus laevis and Hymenochirus spp. are used for scientific research (Iskandar 1998), while Ceratophrys spp. from Latin America are sold as pets (Iskandar 1998, M. D. Kusrini pers. obs.). All species mentioned above have been reported to have $B d$ infections in different countries (Raverty \& Reynolds 2001, Hanselmann et al. 2004, Weldon et al. 2004). Although all exotic species are intended for captive breeding, release into the wild is a possibility. For instance, McKay (2006) reported that a population of $R$. catesbeiana has been established in the lakes of Bratan, Buyan and Tamblingan in Bali. They not only potentially compete with local species but may also introduce disease.

With the finding of $B d$ in Indonesian frogs, there is a need to set up a national protocol to mitigate the spread and impact of $B d$ within Indonesia and neighboring countries as well as raise awareness among local scientists, breeders and traders. A 2007 export quota report from the Indonesian Ministry of Forestry showed that 40 species of frogs are listed for live export (Ditjen PHKA 2007) including 3 species identified as being infected by $B d$ in this report (Rana chalconota, Leptobrachium hasseltii and Rhacophorus javanus). Two of the species with the highest number of live frogs exported from Indonesia for pets are Litoria caerulea (67 500 ind.) and L. infrafrenata (45000 ind.), mostly taken from the Papua region (Ditjen PHKA 2007). Both are also found in the neighboring country of Papua New Guinea and Australia, and are known to be infected by Bd (Pessier et al. 1999, Speare \& Berger 2005). In 2003, an exporter in Jakarta mentioned that most of his batches of Litoria infrafrenata coming from Papua died in his temporary captivity facility for no apparent reason (pers. comm. to M. D. Kusrini). It usually started with 1 or 2 frogs becoming sick and all the frogs in the same container dying within days. In 2007 , the same exporter remarked that he had fewer problems after he found out that a sick frog could be cured 
by letting it out to bask in the sun. This anecdotal account suggests the possibility of $B d$ infection in frogs from other areas of Indonesia. Thus, there is a need to conduct surveys for $B d$ in other parts of Indonesia, especially in the mountainous areas of Java, Sumatra and Papua which would favour the pathogen.

Acknowledgements. We thank the National Park Office of Mount Gede Pangrango, especially N. Bambang and his staff and field officers who helped during the survey. We also thank A. Hamidy and Mumpuni for access to MZB; N. Sholihat, M. Yazid, A. U. Ul-hasanah, B. Darmawan, A. Fitri, D. Susanto, M. Lubis, L. R. Yusuf, N. Widagdi, F. Untoro, R. Rachmadi, D. Ardiansyah, S. D. Riendriasari, F. Irawan, S. Rahmawanto, N. Husna, R. Yossi, Y. Sumitra, Sasikirono, Suwardiansyah, Supri, Delfiandi, Azhari, Ayu, Lanjar, Igor, Utuk, Ae and Pepen who volunteered to help during the survey; S. N. Stuart, R. A. Alford and J. Rowley for valuable comments and advice during the preparation and completion of this research; and 2 anonymous reviewers for valuable advice. Funding for the survey was provided by a BP Conservation Programme Project Grant (No. F200306) to M.D.K., while PCR and histological analyses were funded by James Cook University through an early career research grant to L.F.S. Additional funding was also given by the Australian Government Department of the Environment, Water, Heritage and the Arts to maintain $B d$ expertise and diagnostic testing capacity.

\section{LITERATURE CITED}

Bell BD, Carver S, Mitchell NJ, Pledger S (2004) The recent decline of a New Zealand endemic: How and why did populations of Archey's frog Leiopelma archeyi crash over 1996-2001? Biol Conserv 120:189-199

Berger L, Speare R, Daszak P, Green DE and others (1998) Chytridiomycosis causes amphibian mortality associated with population declines in the rainforest of Australia and Central America. Proc Natl Acad Sci USA 95:9031-9036

Berger L, Speare R, Hyatt A (1999) Chytrid fungi and amphibian declines: overview, implications and future directions. In: Campbell A (ed) Declines and disappearances of Australian frogs. Environment Australia, Canberra, p 23-33

Berger L, Speare R, Kent A (2000) Diagnosis of chytridiomycosis in amphibians by histologic examination. Zoos' Print J 15:184-190

Berger L, Hyatt AD, Olsen V, Hengstberger SG and others (2002) Production of polyclonal antibodies to Batrachochytrium dendrobatidis and their use in an immunoperoxidase test for chytridiomycosis in amphibians. Dis Aquat Org 48: 213-220

Berger L, Speare R, Hines H, Marantelli G and others (2004) Effect of season and temperature on mortality in amphibians due to chytridiomycosis. Aust Vet J 82:31-36

Bosch J, Martinez-Solano I, Garcia-Paris M (2001) Evidence of a chytrid fungus infection involved in the decline of the common midwife toad (Alytes obstetricans) in protected areas of central Spain. Biol Conserv 97:331-337

Boyle DG, Boyle DB, Olsen V, Morgan JAT, Hyatt AD (2004) Rapid quantitative detection of chytridiomycosis (Batrachochytrium dendrobatidis) in amphibian samples using real-time Taqman PCR assay. Dis Aquat Org 60:141-148

> Daszak P, Berger L, Cunningham AA, Hyatt AD, Green DE, Speare R (1999) Emerging infectious diseases and amphi- bian population declines. Emerg Infect Dis 5: 735-748

Daszak P, Cunningham AA, Hyatt AD (2003) Infectious disease and amphibian population declines. Divers Distrib 9:141-150

Daszak P, Strieby A, Cunningham AA, Longcore JE, Brown CC, Porter D (2004) Experimental evidence that the bullfrog (Rana catesbeiana) is a potential carrier of chytridiomycosis, an emerging fungal disease of amphibians. Herpetol J 14:201-207

Daszak P, Schloegal L, Maranda L, Cronin A, Pokras M, Smith K, Picco A (2006) The global trade in amphibians: summary interim report of a CCM study. Consortium for Conservation Medicine, New York. Available at: www. conservationmedicine.org/factsheets/Amphib_trade_ interim_report_06.pdf

Ditjen PHKA (Direktorat Jenderal Perlindungan Hutan dan Konservasi Alam) (2007) Keputusan Direktorat Jenderal Perlindungan Hutan dan Konservasi Alam Nomor: SK.33/IV-KKH/2007 Tentang Kuota Pengambilan Tumbuhan dan Penangkapan Satwa Liar dari Habitat Alam Periode Tahun 2007. Lampiran 2. Kuota Pengambilan Tumbuhan dan Penangkapan Satwa Liar yang Tidak termasuk Appendiks CITES untuk Periode 2007. Indonesian Ministry of Forestry, Jakarta

- Fisher MC, Garner TWJ (2007) The relationship between the emergence of Batrachochytrium dendrobatidis, the international trade in amphibians and introduced amphibian species. Fungal Biol Rev 21:2-9

> Hanselmann R, Rodríguez A, Lampo M, Fajardo-Ramos L and others (2004) Presence of an emerging pathogen of amphibians in introduced bullfrogs Rana catesbeiana in Venezuela. Biol Conserv 120:115-119

Hyatt AD, Boyle DG, Olsen V, Boyle DB and others (2007) Diagnostic assays and sampling protocols for the detection of Batrachochytrium dendrobatidis. Dis Aquat Org 73: 175-192

Iskandar DT (1998) Amfibi Jawa dan Bali. Puslitbang BiologiLIPI, Bogor

IUCN (International Union for Conservation of Nature and Natural Resources) (2008) 2008 IUCN Red List of Threatened Species. Available at: www.iucnredlist.org/details/ 54815 (accessed 26 October 2008)

Knapp RA, Morgan JAT (2006) Tadpole mouthpart depigmentation as an accurate indicator of chytridiomycosis, an emerging disease of amphibians. Copeia 2006:188-197

Kusrini MD (2005) Edible frog harvesting in Indonesia: evaluating its impact and ecological context. PhD dissertation, James Cook University, Townsville

Kusrini MD, Fitri A, Utama H, Nasir DM, Ardiansyah D, Lestari V, Rachmadi R (2005) Project 202404: ecology and conservation of frogs of Mount Gede Pangrango National Park. Technical report submitted to BP Conservation Program. Institut Pertanian Bogor, Bogor

Kusrini MD, Fitri A, Endarwin W, Yazid M (2007a) The amphibians of Mount Gede Pangrango and Mount Salak, Indonesia. Froglog 81

Kusrini MD, Endarwin W, Yazid M, Ul-Hasanah AU, Sholihat N, Darmawan B (2007b) The amphibians of Mount Gede Pangrango National Park. In: Kusrini MD (ed) Frogs of Gede Pangrango: a follow up project for the conservation of frogs in West Java, Indonesia, Book 1. Main report. Technical report submitted to the BP Conservation Programme. Institut Pertanian Bogor, Bogor, p 11-31

> Laurance WF (2008) Global warming and amphibian extinctions in eastern Australia. Austral Ecol 33:1-9

Liem DSS (1971) The frogs and toads of Tjibodas National Park, Mt. Gede, Java, Indonesia. Philipp J Sci 100:131-161 
Lips KR (1999) Mass mortality and population declines of anurans at the upland site in west Panama. Conserv Biol 13:117-125

Lips KR, Mendelson JR, Munoz-Alonso A, Canseco-Marquez L, Mulcahy DG (2004) Amphibian population declines in montane southern Mexico: resurveys of historical localities. Biol Conserv 119:555-564

Lips KR, Diffendorfer J, Mendelson JR III, Sears MW (2008) Riding the wave: reconciling the roles of disease and climate change in amphibian declines. PLoS Biol 6:e72

Longcore JE, Pessier AP, Nichols DK (1999) Batrachochytrium dendrobatidis gen. et sp. nov., a chytrid pathogenic to amphibians. Mycologia 91:219-227

- Marsh DM (2001) Fluctuations in amphibian populations: a meta-analysis. Biol Conserv 101:327-335

McKay JL (2006) A field guide to the amphibians and reptiles of Bali. Krieger Publishing, Malabar, FL

McLeod DS, Sheridan JA, Jiraungkoorskul W, Khonsue W (2008) A survey for chytrid fungus in Thai amphibians. Raffles Bull Zool 56:199-204

Muths E, Corn PS, Pessier AP, Green DE (2003) Evidence for disease-related amphibian decline in Colorado. Biol Conserv 110:357-365

Obendorf DL (2005) Application of field and diagnostic methods for chytridiomycosis in Tasmanian frogs. Central North Field Naturalists, Hobart

Olson D, Ronnenberg K (2008) Batrachochytrium dendrobatidis mapping project: update - 17 January 2008. Accessed 3 Feb. www.parcplace.org/bdmap2008update.html

Pechmann JHK, Wilbur HM (1994) Putting declining amphibian populations in perspective: natural fluctuations and human impacts. Herpetologica 50:65-84

Pechmann JHK, Scott DE, Semlitsch RD, Cadwell JP, Vitt LJ, Gibbons JW (1991) Declining amphibian populations: the problem of separating human impacts from natural fluctuations. Science 253:892-895

Pessier AP, Nichols DK, Longcore JE, Fuller MS (1999) Cutaneous chytridiomycosis in poison dart frogs (Dendrobates spp.) and White's tree frogs (Litoria caerulea). J Vet Diagn Invest 11:194-199

Piotrowski JS, Annis SL, Longcore JE (2004) Physiology of Batrachochytrium dendrobatidis, a chytrid pathogen of amphibians. Mycologia 96:9-15

Raverty S, Reynolds T (2001) Cutaneous chytridiomycosis in dwarf aquatic frogs (Hymenochirus boettgeri) originating from southeast Asia and in a western toad (Bufo boreas) from northeastern British Columbia. Can Vet J 42:385-386

Retallick RWR, Miera V (2007) Strain differences in the amphibian chytrid Batrachochytrium dendrobatidis and non-permanent, sub-lethal effects of infection. Dis Aquat Org 75:201-207

Editorial responsibility: Alex Hyatt,

Geelong, Victoria, Australia
Retallick RWR, Miera V, Richards KL, Field KJ, Collins JP (2006) A non-lethal technique for detecting the chytrid fungus Batrachochytrium dendrobatidis on tadpoles. Dis Aquat Org 72:77-85

Ron SR (2005) Predicting the distribution of the amphibian pathogen Batrachochytrium dendrobatidis in the new world. Biotropica 37:209-221

Rowley JJL, Fung Chan SK, Tang WS, Speare R and others (2007) Survey for the amphibian chytrid fungus Batrachochytrium dendrobatidis in Hong Kong in native amphibians and in the international amphibian trade. Dis Aquat Org 78:87-95

> Skerratt LF, Berger L, Speare R, Cashins S and others (2007) The spread of chytridiomycosis has caused the rapid global decline and extinction of frogs. EcoHealth 4: 125-134

Skerratt LF, Berger L, Hines HB, McDonald KR, Mendez D, Speare R (2008) Survey protocol for detecting chytridiomycosis in all Australian frog populations. Dis Aquat Org 80:85-94

Speare R, Berger L (2005) Chytridiomycosis in amphibians in Australia. James Cook University, Townsville. Available at: www.jcu.edu.au/school/phtm/PHTM/frogs/chyspec.htm (accessed 3 February 2008)

Speare R, Berger L, Skerratt LF, Alford R and others (2004) Hygiene protocol for handling amphibians in field studies. James Cook University, Townsville. Available at: www. jcu.edu.au/school/phtm/PHTM/frogs/field-hygiene.pdf (accessed 3 February 2008)

Speare R, Skerratt L, Berger L, Hines HB, and others (2005) A project that designs and trials a pilot survey to map the distribution of chytridiomycosis (caused by the amphibian chytrid) in Australian frogs. Final report for Project ID 44381 (tender 63/2003) to the Australian Government Department of Environment and Heritage, Canberra. Available at: www.environment.gov.au/biodiversity/ invasive/publications/c-disease/distribution-survey.html (accessed 3 February 2008)

Susanto H (1989) Budidaya kodok unggul. Penebar Swadaya, Jakarta

Une Y (2007) Intrusion of amphibian chytrid fungus into Japan. Proc Joint Meeting of 3rd Meeting of Asian Soc Vet Pathol (ASVP), Assoc Asian Vet School (AAVS), and the 2nd Asian Conserv Med/Wildlife Pathol Workshop (ASZWM), Aug 30-31, 2007, National Taiwan University, Taipei, p 191-192

Weldon C, Du Preez LH, Hyatt AD, Muller R, Speare R (2004) Origin of the amphibian chytrid fungus. Emerg Infect Dis 10:2100-2105

Woodhams DC, Alford RA, Marantelli G (2003) Emerging disease of amphibians cured by elevated body temperature. Dis Aquat Org 55:65-67

Submitted: March 17, 2008; Accepted: September 10, 2008 Proofs received from author(s): October 28, 2008 